\title{
The Case Is Much More Baffling than We Think
}

\author{
Etrat Hooshmandi Afshin Borhani-Haghighi \\ Clinical Neurology Research Center, Shiraz University of Medical Sciences, Shiraz, Iran
}

Dear Editor,

Morelli et al. [1] reported decreased prevalence of stroke during the COVID-19 pandemic era according to their observation from a single center (Guglielmo da Saliceto Hospital, Piacenza, northern Italy). They considered phobia of admission in COVID-affiliated hospitals and the probability of missing minor strokes in seriously involved respiratory distress patients. Meanwhile, they hypothesized that increased interleukin- 6 and thrombocytopenia may result in decreased prevalence of stroke. They concluded that the association of stroke and viral infection, which has been reported previously [2], might not be true for SARS-CoV-2 infection.

Contrary to their conclusion, there are some reports about increased risk of stroke in COVID-19 infection [3]. It has been shown that SARS-CoV-2 infection has not only respiratory manifestations but may also have hematological, cardiac, and nervous system involvement $[4,5]$. COVID-19 infection can lead to myocarditis [6] and abnormalities in the coagulation cascade and vascular endothelial function [7]. Han et al. [8] evaluated the importance of the difference in some blood coagulation parameters between patients with COVID-19 infection and healthy controls. They found blood coagulation in pa-

karger@karger.com

(c) 2020 S. Karger AG, Basel

www.karger.com/ene

Karger" tients with COVID-19 to be obviously deranged [8]. Therefore, it seems that routine monitoring of blood parameters can be helpful in predicting disease progression. In addition, due to the presence of angiotensin-converting enzyme 2 receptors on blood vessels, one of the main targets of the virus are blood vessels. In this way, the virus can lead to the formation of blood clots, or ample bleeding that may be a result of consuming clotting factors. Recently, Oxley et al. reported a 7-fold increase in the risk of stroke incidence by finding large vessel stroke in five COVID-19 patients with age $<50$ years over a 2 -week period (as a letter published online April 28 in the New England Journal of Medicine. DOI: 10.1056/ NEJMc2009787).

Considering the anecdotal and unpublished reports of stroke subsequent to COVID-19 infection, at the present time, it is too early to consider the "cause and effect," but further prospective and large-volume studies are warranted. We think that the decreasing trend of stroke in Morelli et al.'s [1] center is mostly related to delayed or cancelled access of the stroke victims and their family due to phobia of COVID-19 infection. Further, people tend to ignore symptoms other than those of COVID-19 in this condition. This issue has been 
mentioned in other disciplines as well. Similarly in Italy, a $73-88 \%$ decrease in emergency visits for the pediatric age-group at the time of the COVID-19 pandemic has been noted in comparison to that in the same time period in the previous years [9]. Only international multicenter studies may lead us to find the changes in trend of different types of cerebrovascular diseases during the COVID-19 pandemic.

\section{Disclosure Statement}

The authors have no conflicts of interest to declare.

\section{Funding Sources}

The authors did not receive any funding.

\section{Author Contributions}

Etrat Hooshmandi: Writing the manuscript and approval of the final version. Afshin Borhani-Haghighi: Drafting, conception and critical revision of the manuscript for important intellectual content, and approval of the final version.

\section{References}

1 Morelli N, Rota E, Terracciano C, Immovilli P, Spallazzi M, Colombi D, et al. The baffling case of ischemic stroke disappearance from the casualty department in the COVID-19 Era. Eur Neurol. 2020 Apr 14.

2 Boehme AK, Esenwa C, Elkind MS. Stroke risk factors, genetics, and prevention. Circ Res. 2017 Feb;120(3):472-95.

3 Klok F, Kruip M, Van der Meer N, Arbous M, Gommers D, Kant $\mathrm{K}$, et al. Incidence of thrombotic complications in critically ill ICU patients with COVID-19. Thromb Res. 2020 Apr;3848(20):30120-1.
4 Fan B, Chong V, Chan S, Lim G, Lim K, Tan $\mathrm{G}$, et al. Hematologic parameters in patients with COVID-19 infection. Am J Hematol. 2020 Jun; 95(6):E131-4. https://doi.org/ 10.1002/ajh.25774.

5 Driggin E, Madhavan MV, Bikdeli B, Chuich T, Laracy J, Biondi-Zoccai G, et al. Cardiovascular considerations for patients, health care workers, and health systems during the COVID-19 pandemic. J Am Coll Cardiol. 2020 Mar;75(18):2352-71.

6 Zheng YY, Ma YT, Zhang JY, Xie X. COVID-19 and the cardiovascular system. Nat Rev Cardiol. 2020 May;17(5):259-60.
7 Zhou F, Yu T, Du R, Fan G, Liu Y, Liu Z, et al. Clinical course and risk factors for mortality of adult inpatients with COVID-19 in Wuhan, China: a retrospective cohort study. Lancet. 2020 Mar;395(10229):1054-62.

8 Han $\mathrm{H}$, Yang L, Liu R, Liu F, Wu KL, Li J, et al. Prominent changes in blood coagulation of patients with SARS-CoV-2 infection. Clin Chem Lab Med. 2020 Mar. ahead-of-print.

9 Lazzerini M, Barbi E, Apicella A, Marchetti F, Cardinale F, Trobia G. Delayed access or provision of care in Italy resulting from fear of COVID-19. Lancet Child Adolesc Health. 2020 May;4(5):e10-1. 